DOI: $\underline{\text { http://dx.doi.org/10.17793/rdd.v5i8.871 }}$

\title{
3. ANTÍGONA $X$ CREONTE: O RESPEITO AO CADÁVER, OS DIREITOS DA PERSONALIDADE E A RESPONSABILIDADE CIVIL
}

\author{
3. ANTIGONE X CREON: CORPSE RESPECT, PERSONALITY \\ RIGHTS AND TORTS
}

\author{
Guilherme Damasio Goulart ${ }^{1}$ \\ Kelly Lissandra Bruch ${ }^{2}$
}

\begin{abstract}
Resumo. Este artigo objetiva, a partir da análise da peça Antígona, imortalizada por Sófocles, estudar situações relacionadas ao cuidado com o cadáver, sob a ótica do Jus Sepulchri. Tendo como ponto de partida a devoção e a determinação de Antígona em dar ao irmão morto as honras fúnebres, analisa-se como,. dentro do Direito Civil atual e do Código de Defesa do Consumidor, é possível estudar o problema do cuidado com o cadáver, sob a ótica do direito da personalidade e da responsabilidade civil. Como resultado, verifica-se a existência de inúmeros e recentes julgados que tocam os direitos relacionados ao Jus Sepulchri, podendo concluir-se que, apesar de remontar aos primórdios da humanidade, trata-se de tema atual e cuja violação de direitos ainda consterna a sociedade.
\end{abstract}

Palavras-chave. Antígona, cadáver, Jus Sepulchri, Direito ao Cadáver, Direitos da Personalidade, Responsabilidade Civil, restos mortais.

\begin{abstract}
This article aims, from the analysis of the play called Antigona - immortalized by Sophocles - to study some situations related to the care of corpse, from the perspective of Jus Sepulchri. Taking as a starting point Antigone's devotion and determination in give to your dead brother the funeral honors, is shown as, within the current Civil Law and Consumer Protection Law, how is possible to study the care's corpse problem from the perspective of personal rights and torts. As a result, can be verified the existence of numerous judicial decisions related to Jus Sepulchri's rights, and may be concluded that, although this subject dates back to the beginnings of humanity, it is a current topic and your violation still dismay the society.
\end{abstract}

$1 \mathrm{O}$ autor é Advogado, Mestre em Direito pela UFRGS e professor do curso de graduação em Direito no CESUCA e de pós-graduação em diversas instituições.

2 Doutora em Direito, Professora do Departamento de Direito Econômico e do Trabalho, Faculdade de Direito/UFRGS, Professora do Programa de Pós-Graduação em Agronegócios, Centro de Estudos e Pesquisa em Agronegócio - CEPAN/UFRGS, Professora Pesquisadora da CESUCA/Faculdade INEDI.

Rua Silvério Manoel da Silva, 160 - Bairro Colinas - Cep.: 94940-243 | Cachoeirinha - RS | Tel/Fax. (51) 33961000 | e-mail: cesuca@cesuca.edu.br 
KeyWords. Antigone, Corpse, Jus Sepulchri, XXX, Civil Riths Rights, Torts.

\section{PARA INICIAR, UMA INTRODUÇÃO À TRAGÉDIA GREGA}

Analisar uma tragédia grega, já estudada centenas de vezes, parece uma das tarefas mais ingratas, senão desnecessária. Todavia, percebe-se que sempre há possibilidade de lançar novos olhares a obras que, por sua autenticidade, complexidade, robustez, e tantos outros adjetivos, ultrapassaram os milênios. E é este desafio que se pretende enfrentar no presente artigo, analisando Antígona no âmbito do direito civil.

Na presente abordagem, busca-se fugir um pouco da lógica tradicional que se encontra no direito ao analisar a obra Antígona. Segundo Alves (2007. p. 25):

Via de regra, ela é citada nos curso de Direito meramente para ilustrar o conflito entre Direito Natural e Direito Positivo, e quase sempre para destacar uma suposta vitória incontestável do Direito Natural. Dito de outro modo, Antígona, e não apenas ela, acaba muitas vezes sendo citada a título de curiosidade, para testemunhar a suposta cultura daquele que a cita e conferir certo 'verniz' ou 'perfume' à formação técnica dos acadêmicos postura esta que, por certo, em nada favorece a compreensão crítica da obra. (destaque no original)

Segundo o Alves (2007), o uso da literatura clássica deve, a partir do contexto criado pela obra, buscar compreender o aspecto jurídico a partir desta, tratando-se muito mais de problematizar este aspecto a partir do enredo, valorizando elementos religiosos, socioculturais e políticos apenas subentendidos na obra e que possam ser uteis à construção da leitura proposta. Não se deve esquecer, todavia, de contextualizar a obra em seu período de elaboração, seu propósito e sua contextualização histórica. Só assim a construção de análises críticas com base no Direito \& Literatura serão passíveis de "desmistificar leituras simplistas que comprometem substancialmente o reconhecimento do alcance da obra" (ALVES, 2007, p. 27).

Finaliza Alves (2007. p. 27), explanando que:

[...] a expectativa é que o mérito do ensaio seja medido, como é de se esperar de um texto introdutório, pelo tanto que puder despertar de interesse pela obra analisada, pela temática abordada e - por que não? pela construção crítica do conhecimento.

Em face destas observações, outras questões precisam ser levantadas. O que era uma tragédia grega? Qual era seu propósito? Foi efetivamente Sófocles o autor de Antígona?

Sem adentrar a origem mítica da tragédia, esta possuía, na Grécia - notadamente no apogeu do período democrático que ocorre nos séculos VI e V a.C. - um papel estreitamente 
vinculado à política e aos interesses e projetos da Cidade Estado grega de Atenas. Segundo Alves (2007, p. 37), a tragédia servia

[...] à educação moral e política dos cidadãos em geral. O drama convidava os espectadores a refletirem sobre que ações e valores deveriam ser cultivados pelo novo homem que a pólis democrática fizera surgir.

Segundo Alves (2007, p. 39) “[...] no mito, o que irá interessar ao poeta trágico não é propriamente o herói, mas a ação que ele comete". (grifo nosso)

Para Aristóteles (1984, p. 245):

É pois a tragédia imitação de uma ação de caráter elevado, completa e de certa extensão, em linguagem ornamentada e com várias espécies de ornamentos distribuidas pelas diversas partes [do drama] , [imitação que se efetua] não por narrativa, mas mediante atores que, suscitando o "terror e a piedade, tem or efeito a purificação destas emoções (colchetes e aspas no original).

Por fim, é relevante citar que as peças teatrais que eram apresentadas referiam-se à mitologia, a um passado remoto para os próprios gregos que, no século $\mathrm{V}$ a. C., assistiam a estas tragédias. Assim como Antígona, outros mitos foram escritos por diversos autores e representados. Antígona não pertencia a Sófocles, este apenas a estruturou da forma que permaneceu até a atualidade, o mesmo se deu com Édipo Rei. Prometeu acorrentado, outro mito conhecido, foi imortalizado por Ésquilo, por exemplo.

Segundo Alves (2007, p. 44):

\begin{abstract}
Ao se valer da figura mitológica dos heróis da nobreza antiga, os quais não reconheciam limites, pelo menos não num primeiro momento do drama, o poeta conseguia expor ao público que a ação desmedida e à margem da lei acarreta um prejuizo alto para seu responsável, muitas vezes afetando toda a sociedade. Para o espectador da tragédia, o sofrimento do herói diante de sua transgressão traduzia-se, em boa medida, numa advertência poética e política facilmente entendida.
\end{abstract}

Essa era, portanto, a maneira como, naquele momento, se dava a educação moral e ética do povo grego, por meio do uso dos mitos, das tragédias e de suas representações, em teatros que poderiam, a um só tempo acomodar milhares de pessoas.

\title{
2. O QUE É ANTÍGONA?
}

Terceira parte da Trilogia Tebana de Sófocles, esta é composta por Édipo Rei, Édipo em Colono e Antígona. Antígona é um tragédia grega clássica, que chegou aos dias atuais pela sua importância histórica, mas também pela sua atemporalidade. 
A história de Antígona inicia-se em decorrência do momento em que Édipo, ao descobrir que havia cumprido a profecia de matar seu pai Laio e casar com a sua mãe Jocasta, exila-se de Tebas. Com o exílio, um dos filhos homens de Édipo, Polinices ou Etéoces, deve assumir o reinado sobre Tebas. Neste momento os dois fazem um acordo: cada um governará pelo período de um ano, a começar por Etéocles.

Todavia, ao fim do primeiro ano, Etéocles recusa-se a ceder o trono ao irmão. Polinices, furioso, sai da cidade e vai a Argos, cidade inimiga de Tebas. Nesta, casa-se com a filha do rei e convence-o a apoiá-lo a tomar Tebas à força. Na batalha os irmãos morrem um pela mão do outro, saindo Tebas vitoriosa. Com a morte dos irmãos, o tio destes, Creonte, irmão de Jocasta, torna-se o sucessor natural do Trono.

Neste momento Creonte edita um decreto, que Antígona narra a Ismene:

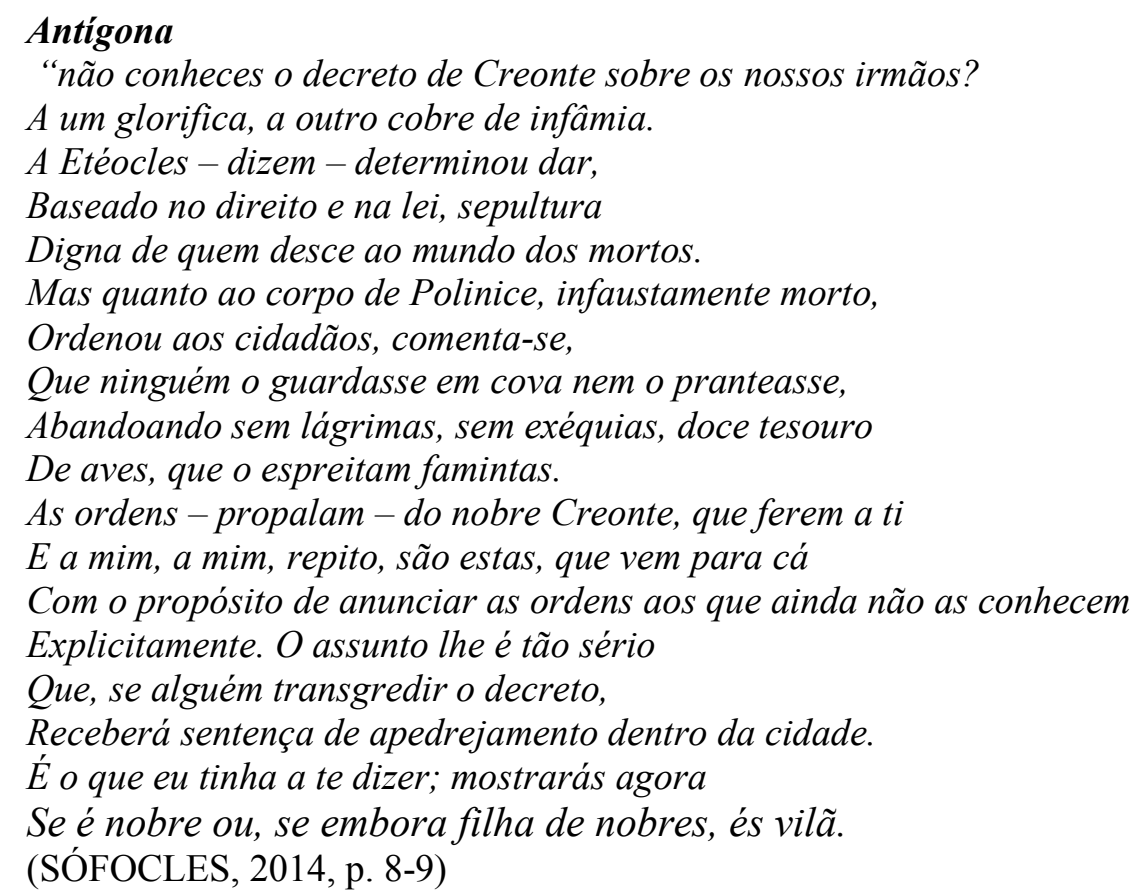

É neste contexto que se inicia a tragédia. Antígona, irmã de Polinices e também de Etéocles - este também morto mas que recebeu um enterro apropriado - entende ser totalmente injusto deixar o irmão insepulto. Logo no início da peça nota-se o absoluto desconforto das irmãs Ismene e Antígona com a questão. Ismene chega a perguntar a Antígona, quando ambas conversam sobre a possibilidade de enterrar o irmão insepulto, como elas poderiam enfrentar sozinhas os homens, se elas são mulheres (SÓFOCLES, 1990).

Mesmo assim, Antígona realiza o enterro de seu irmão. O relato do guarda ao rei Creonte (aquele testemunhara o ato) indica que o corpo não estava bem enterrado, dando a entender que alguém o tivera enterrado com as próprias mãos (SÓFOCLES, 1990). Isso 
ISSN 2316-2112

denota a importância e a necessidade de que se enterrem os mortos eis que "enterrar com as próprias mãos" traduz-se no fato de que ela chegou ao extremo para garantir a destinação adequada do corpo do irmão. Isso por que, na cultura grega, não enterrar o morto significava deixá-lo vagando entre a vida e a morte, como fantasmas, se ter a oportunidade de ir para o mundo dos mortos.

Creonte decide então, por ela ter violado a lei, enterrá-la viva em uma caverna. Este ato também deve ser observado com atenção: Creonte, assim o fazendo, deixaria Antígona também sem as honras funerárias, visto que ela morreria de inanição, sozinha já na caverna fechada, mas não aplicaria o apedrejamento. Tirésias - o adivinho - alerta Creonte deste erro "pois tu lançaste às profundezas um ser vivo e ignobilmente o sepultaste, enquanto aqui reténs um morto sem exéquias, insepulto..."(SÓFOCLES, 1990, p. 145). Creonte, sentindo o erro e aconselhado pelo corifeu, decide soltar Antígona e enterrar Polinices. Hêmom, filho de Creonte, por sua vez, era apaixonado por Antígona. Quando sabe que ela fora enterrada, vai até ela e a descobre morta. Antígona cometera suicídio. Arrebatado pela visão e pela emoção, Hêmom tenta matar o pai, que assiste a cena e consegue se proteger. Logo depois comete suicídio deitando sobre sua própria espada. A mãe de Hêmom também se mata após saber da morte do filho. Creonte diante do filho e da esposa mortos, arrepende-se e lamenta seus atos.

E a tragédia termina, com Creonte falando com o Corifeu ${ }^{3}$ :

\author{
Creonte \\ Levai para longe este insensato, \\ Que, ó filho, meu, não te matou deliberadamente, \\ Nem a esta [sua esposa]. Ai de mim, \\ Já não sei o que fazer, \\ Para quem olhar. \\ Tudo o que tenho nas mãos vacila, \\ E sobre minha cabeça \\ A fatalidade desaba, insuportável.

\section{Corifeu} \\ A prudência é, em muito, \\ A primeira das venturas. \\ Contra os deuses \\ Não convém agir. Palavras altivas \\ Trazem aos altivos \\ Castigo atroz. \\ Velhice ensina prudência. \\ (SÓFOCLES, 2014, p. 90-91)
}

3 Corifeu: personagem composto por um conjunto de atores e representando, quase sempre, o ponto de vista dos cidadãos, da comunidade cívica. ALVES, Ibidem, p. 39 
ISSN 2316-2112

Ao final, portanto, resta a prudência, para que o calor das paixões não leve a atos desmesurados que possam implicar na sua própria destruição. A prudência no cuidado e a prudência no dever, são a moral da história, elemento finalizador de toda a tragédia grega.

\section{ANTÍGONA: O QUE HÁ DE INTERDISCIPLINAR NESTA OBRA}

Estudar Antígona, já perscrutada tantas vezes, por filósofos, sociólogos, juristas, psicólogos, psiquiatras e pedagogos, ilustra o efetivo significado de um desafio 4 .

Tradicionalmente o texto de Sófocles tem sido tratado no âmbito do embate entre direito natural e direito posto, entre o que Reale chamou de "justo por natureza e o justo por convenção" (REALE, 1999, p. 622). A maioria dos trabalhos acadêmicos envolve a referida abordagem (ALVES, 2007, p. 25).

Tanto o é que, para Alves (ALVES, 2007, p. 25) muitos autores apenas conseguem vislumbrar que por meio de Antígona pode-se "ilustrar o conflito entre Direito Natural e Direito Positivo, e quase sempre para destacar uma suposta vitória incontestável do Direito Natural", sem considerar que, à época em que a tragédia foi escrita, este conflito não existia, tão pouco o direito positivo ou a lógica moderna de direito natural. Isso faz refletir sobre como versar sobre um texto literário, especialmente um clássico da antiguidade, para buscar, por meio dele, uma abordagem atual e ao mesmo tempo condizente com o escopo da obra analisada. Conforme pode ser visto na sequencia, várias abordagens podem ser evidenciadas, como por exemplo no âmbito da criminologia, no direito penal, na questão do feminismo, na psicanálise, na proteção àqueles que se encontram em estado de vulnerabilidade, dentre outros.

O cuidado com os mortos, evidenciado nesta obra, projeta-se ao longo dos tempos e permanece até hoje. Diz-se, até mesmo, que o embrião das religiões aparece com o culto aos mortos, visto que o homem, aí, percebe a ideia do sobrenatural (COULANGES , 1981, p. $27)^{5}$. Acreditava-se, à época, que alma e corpo não se separavam mesmo depois da morte. Os rituais fúnebres evidenciavam o fato de que se pensava estar colocando no túmulo algo ainda vivo (COULANGES , 1981, p. 16). Tanto é assim que não era incomum que se enterrassem

4 Neste sentido vide: ALVES, 2007; PANDOLFO, 1977; BUTLER, 2014; VORSATZ, 2013; ALBORNOZ, 1999; MARINHO, 1980.

5 Mais adiante, o autor diz que a ideia do culto aos mortos não se compararia ao culto aos santos promovido pelos cristãos, sendo, portanto, cultos absolutamente diferentes, p. 36 . 
as pessoas com alguns pertences pessoais (COULANGES , 1981, p. 17). Quando Antígona é pega tentando enterrar seu irmão novamente, é claro o relato do guarda quando diz que ela "levantando um gracioso jarro brônzeo derramou sobre o cadáver abundante libação" (SÓFOCLES, 1990, p. 129). Sobre este costume, Coulanges explica que "derramava-se vinho sobre o túmulo para lhe mitigar a sede...", sendo possível encontrar essa prática em outros escritores como Eurípides e Ésquilo (COULANGES , 1981, p. 17 e 21).

Igualmente, a cerimônia fúnebre deveria ser promovida pelo parente mais próximo (COULANGES , 1981, p. 36). Tais práticas eram vistas como uma obrigação relacionada com o culto aos mortos, vistos estes como entes sagrados (COULANGES , 1981, p. 22 e 23) ${ }^{6}$. Não se podia simplesmente ignorar tais obrigações e deixar de realizar as tais libações. Por isso o impacto da obra de Sófocles por conceber uma situação envolvendo o corpo insepulto. Assim, é fundamental a consideração desses aspectos míticos e religiosos para a proteção do morto.

A prática da época era clara em pregar, conforme Coulanges, que o corpo que não tivesse seu túmulo "não teria morada [...] era errante [...] a alma vive(ria) desgraçada" (COULANGES , 1981, p. 18). A intenção de Antígona de preferir a morte do que deixar o irmão insepulto confirma a lição de que se temia menos a morte do que não ser adequadamente sepultado. A situação de não sepultamento passa a ser, portanto, uma pena imposta à alma do morto (COULANGES , 1981, p. 19) ${ }^{7}$.

A intenção de Antígona em dar um enterro digno ao parente e a obra como um todo pode ser vista como uma grande manifestação do costume ancestral e universal do respeito aos mortos. Vê-se que o ato de Antígona é um ato de extremo heroísmo. Tal heroísmo ocorre em um panorama de heróis homens e Antígona, de fato, se emancipa como cidadã ${ }^{8}$ e como mulher quando vai de encontro à ordem injusta. Ela luta, de certa forma, também contra o poder masculino. Antígona foi uma mulher de coragem também por se levantar contra a dominação em um mundo comandado por homens (TORRANCE, 2010, p. 240). Esta é uma interessante interpretação, nem sempre destacada nas obras que analisam Antígona.

Ressalta-se que não é apenas em Antígona que se fala sobre a questão do corpo insepulto. A mitologia grega também fala no caso de Heitor, morto por Aquiles, que jurara deixar seu corpo sem ser enterrado. Aquiles mudou de ideia, contudo, após o pedido de Príamo, pai de Heitor (MAGNO, 19--, p. 209):

6 As institutas de Justiniano, seguindo essa tradição, posteriormente, apontavam também que "Qualquer pessoa, por sua vontade, pode tornar religioso um sítio, bastando para isso seupultar um morto em sítio seu", cf. (JUSTINIANUS, , 2001, p, 58)

7Ver também em SÓFOCLES, 1990, p. 143: "Matar de novo um morto é prova de coragem?"

8 Lembrando que apenas os homens eram considerados cidadãos da Polis grega. 
Na noite seguinte, o rei Príamo foi à tenda de Aquiles, lançou-se de joelhos a seus pés pedindo-lhe em lágrimas os restos inanimados de seu filho e oferecendo-lhe uma grossa quantia para resgate. Aquiles que havia jurado deixar o corpo de Heitor sem sepultura e abandoná-lo para ser devorado pelos cães e pelas aves, mas à vista desse velho Príamo suplicante que the falava também do seu velho pai, permitiu-lhe levar os tristes restos do seu filho querido".

Sob outro aspecto de análise, muito abordado pela psicanálise, é possível dizer que Antígona repete a própria relação, ou ao menos o amor incestuoso, dos próprios pais - Édipo e Jocasta - em relação ao irmão - Polinice. Diz ela: "repousarei ao lado dele, amada por quem tanto amei" (SÓFOCLES. 1990, p. 119). Essa questão é notada por Butler, quando diz que a luta pelo irmão é "intensamente carregada de um significado incestuoso" (2006, p. 236). No mesmo sentido Torrance fala sobre a "obsessiva lealdade ao seu irmão", sobre como a relação era "anormal e perturbada" (TORRANCE, 2010, p. 240 e 251). Na visão desta autora haveria ainda uma ligação incestuosa entre Antígona e Édipo, que segundo ela pode ser vista na outra obra da trilogia tebana, "Édipo em Colono" e, com a morte de Édipo, tal ligação teria sido transferida para o irmão (TORRANCE, 2010, p. 252). Essa obsessão de Antígona pelo irmão ultrapassa, na visão de Lacan, o próprio aspecto religioso e sagrado do respeito aos mortos (LACAN, 2008, p. 302).

Ainda sob este enfoque mas tratando da questão da culpabilidade, o ato de Antígona é heroico por que também se trata de uma confissão. Ela confessa seu ato e sabe que seu destino será a morte. A explicação para o ato pode ser encontrada no próprio estudo da criminologia. Butler cita um artigo de Freud (Criminal From a Sense of Guilt) que trata sobre a questão da culpa e do remorso. Nele diz que há um "obscuro sentimento de culpabilidade" em algumas pessoas que poderia estar relacionado com o complexo de Édipo e funciona como uma "reação às grandes intenções criminais de matar o pai e ter relações sexuais com a mãe"

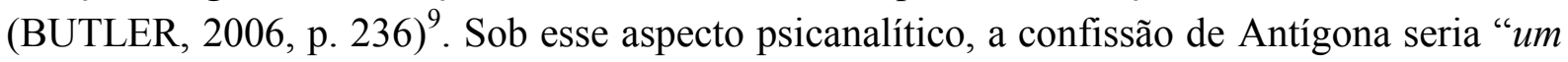
ato suicida impulsionado por um obscuro sentimento de culpa" (BUTLER, 2006, p. 241). Essa pode ser uma ponte para estudar Antígona do ponto de vista do direito penal ou da criminologia.

Muitos abordaram os tais aspectos psicanalíticos da obra de Sófocles. Lacan no seu “A ética da psicanálise" fala bastante sobre a peça, e em geral, sobre a função do belo e da tragédia. Assim, Antígona trata de paixões como o temor e a piedade (LACAN, 2008, p. 294). Segundo ele, a imagem de Antígona seria absolutamente fascinante "para além da família e da pátria, para além dos desenvolvimentos moralizados" ela também seria uma "vítima tão terrivelmente voluntária" (LACAN, 2008, p. 294). Isso pois Antígona já sabe, desde o início, que seu ato também a levará a morte (LACAN, 2008, p. 337).

9 Tais questões desvelam os diversos aspectos e visões psicanalíticas da obra. 
ISSN 2316-2112

Diante dessa visão é possível notar em Antígona alguém que se preocupa com o outro, com o próximo. Essa visão, hoje, aponta o paralelo com o cuidado, cada vez maior, que o direito tem aqueles considerados em estado de vulnerabilidade. Esse sentimento foi notado por Edgar Morin quando diz que se nota, em Antígona, uma ética para o próximo consubstanciada na "piedade, compaixão, amor em favor de um proscrito, de um pária, de um maldito..." (MORIN, 2006, p. 54).

Porém, o que se objetiva neste artigo é abordar a situação do corpo insepulto e suas consequências para o direito. Que direitos há sobre o cadáver? As pessoas possuem o direito de buscar indenizações por ofensas aos restos mortais de um parente morto?

É esta abordagem, objetivando responder a estas questões, que conduziram o presente artigo.

\section{ANTÍGONA: DO CUIDADO ANCESTRAL AO DEVER DE CUIDADO COM O CADÁVER}

A maioria - senão todos - dos ordenamentos jurídicos estabelece proteção aos mortos e a seus restos mortais, sobretudo, como um dos valores sociais - e neste caso ancestrais - dos seres humanos (CHAVES, 1977, p. 159).

No Brasil, o direito irá se preocupar com a proteção do cadáver: em primeiro lugar por meio do Direito Penal, quando tipifica e criminaliza os atos contra o respeito aos mortos, estabelecidos nos artigos 209 a 212 do Código Penal; também por meio do Direito Administrativo ao envolver a organização de cemitérios públicos e indicação de regras gerais de funcionamento para os demais cemitérios; e por meio do Direito Civil, tratando desde a responsabilidade civil pelos atos atinentes a danos causados ao cadáver até as relações contratuais de prestação de serviços e venda de produtos funerários (CHAVES, 1977, p. 161).

Embora a doutrina não trate com muita frequência sobre esses temas, é cediço que praticamente qualquer pessoa, em algum momento, irá deparar-se com a morte de um familiar e, consequentemente, necessitará providenciar o enterro deste. Lidar com a morte e com os serviços necessários ao cuidado e destinação dos cadáveres são situações absolutamente comuns da vida de qualquer pessoa, embora - assim como a morte - sejam fatos e atos pouco tratados, comentados, trabalhados, inclusive no direito.

Embora pouco evidenciados, são conhecidos os casos de planos de serviços funerários onde alguém, com a intenção de diminuir os incômodos de sua família com sua partida (MARQUES, 2014, p. 550), paga um valor mensal com a promessa de que, na ocorrência de 
sua morte, este plano irá prestar todos os serviços necessários desde a liberação do corpo a seu enterro.

Para Marques (2014, p. 550):

O homem pós-moderno é um sujeito de direitos até na morte: quer uma morte independente, que não onere seus familiares, que não "incomode" em demasia. [...] Para alcançar esta segurança de morte digna, aceita contratar, prever, transferir tarefas a terceiros que - confia - realizarão seus serviços com a qualidade e boa-fé, acompanhando-o neste último contrato de consumo, a garantir um enterro digno, serviços funerários de qualidade e um fim apropriado para a imagem que forjou de si próprio (grifo nosso).

Marques aponta que são bastante comuns tais planos que evoluíram para modelos de “assistência funerária total” (MARQUES, 2014, p. 549). Todavia, há vários problemas em tais contratos. Um deles é que são prestados, muitas vezes, por pequenas funerárias (MARQUES, 2014) que nem sempre possuem estrutura de atendimento adequado.

A ideia de um direito à sepultura é algo que pode ser estudado também no âmbito do direito das coisas. Aventa-se a hipótese do direito de sepultura ser um direito real, hipótese de difícil defesa em função dos direitos reais serem numerus clausus, ou seja, seriam reais apenas aqueles direitos estabelecidos na lei (LORENZETTI , 1999, p. 380). Independente da natureza jurídica, entende-se que as relações envolvendo imóveis contendo sepulturas devem manter a indivisibilidade do referido imóvel (LORENZETTI, 1999, p. 381).

De toda a forma, pode-se afirmar que há um ramo autônomo do direito chamado de Direito Funerário. Segundo Justino da Silva (1990, p. 20),

[...] direito funerário é o sistema de normas e principios éticos-sociais que organiza e disciplina as relações decorrentes da morte de uma pessoa natural que se estabelecem entre pessoas e em relação a determinados lugares destinados aos mortos ${ }^{10}$.

Invoca-se este autor, justamente, pois ele retoma o conceito de jus sepulchri ${ }^{11}$, ou seja, o "direito-a-ser-sepultado, direito-de-permanecer-sepultado, direito-à-sepultura $[\ldots] \quad e$

10 O referido autor, ao que se sabe, é o maior especialista brasileiro sobre o tema.

11 Também citado em alguns julgados. Vide, por exemplo: "Ementa: DIREITOS A SER SEPULTADO, A PERMANCER SEPULTADO, À SEPULTURA E A SEPULTAR. O ius sepulchri pertence a esfera própria a dignidade humana e transpõe a mera qualificação de direito público. Distinção entre direito a ser sepultado e direito de sepultar, sendo este último titularizado pelo Estado. Demanda que cuida, todavia, do direito a ser sepultado. Critério de divisão de competência no Tribunal de Justiça estabelecido com base no direito público que permeia a atuação estatal, e não a todo e qualquer direito que se possa deixar de classificar como estritamente privado. Competência afirmada. Direitos a receber exéquias, ser sepultado e permanecer sepultado que não se compadece com defesa de 
ISSN 2316-2112

direito-de-sepultar" (SILVA, 1990, p. 20). Haveria, portanto, considerando o jus sepulchri, um direito de ser sepultado e que, com a morte da pessoa, transmuda-se, para os herdeiros ou sucessores, no direito de sepultar (SILVA, 1990, p. 21). Este direito também deve ser observado pelo poder público para enterrar aqueles que, por alguma razão - falta de dinheiro, parentes desconhecidos, indigência - não possuem parentes aptos a arcar com tal responsabilidade (SILVA, 1990, p. 22).

A simples verificação do desdobramento do jus sepulchri nestes outros direitos pode ser melhor compreendida diante da obra de Sófocles. Não lutou Antigona, durante toda a peça, pela busca do jus sepulchri? Um dos temas centrais do livro parece ser o aspecto sagrado do dever de sepultar-se os mortos. Por isso que, ainda hoje, choca e causa repulsa as cenas de guerras, em locais distantes, onde os corpos jazem insepultos.

O direito romano possuía a chamada actio sepulchri violati, que era utilizada quando alguém violava uma sepultura (SAVIGNY, 1878, p. 330) ${ }^{12}$. Pontes de Miranda aponta que havia até a possibilidade do uso da actio popularis em situações de sepulchro violato:

[...] para que qualquer cidadão pedisse a aplicação da multa por violação de sepulcro, mostra que a actio compete a outra que o titular do direito subjetivo: [...] se não houver alguém a quem pertença, ou não queira exercer a ação, dou-a a quem quer que a queira exercer por cem áureos. (PONTES DE MIRANDA, 1970, p. 499)

No âmbito dos direitos da personalidade sabe-se que estes direitos terminam com a morte: mors ominia solvit (SZANIAWSKI, 1993, p. 303). A existência da pessoa termina com esse fato, conforme o próprio art. $6^{\circ}$ do CC. Tanto que não há mais pessoa quando ocorre o evento morte. A morte afasta a função vital do corpo fazendo com que, deixando de existir a pessoa, surja o cadáver (CUPIS, 2008, p. 98). Não é por que alguém morreu, contudo, que o cadáver não tenha nenhuma importância no ordenamento jurídico. Como se vê em Antígona, e na vida real, ocorre justamente o contrário. Basta evocar o caso Amarildo:

[...] um ajudante de pedreiro brasileiro que ficou conhecido nacionalmente por conta de seu desaparecimento, desde o dia 14 de julho de 2013, após ter sido detido por policiais militares e conduzido da porta de sua casa, na Favela da Rocinha, em direção a sede da Unidade de Polícia Pacificadorado bairro. Seu desaparecimento tornou-se símbolo de casos de

mercado.” (TJ/RS. 20 a Câmara Cível. AC n. 70002434710. Rel. Des. Armínio José Abreu Lima da Rosa, j. 25/04/2001)

12 A referida ação, conforme Savigny, era intentada por aqueles que "tienen derecho para exigir una reparacion de aquellos que han violado una tumba, son á quienes personalmente puede interesar la violacion los hijos del difunto, aun cuando hayan renunciado la sucesion y los herederos. Su accion es una pura vindicta que procura el pago de una cantidad cuya fijacion es arbitraria...", (1878, p. 349.) 
abuso de autoridade e violência policial. Os principais suspeitos no desaparecimento de Amarildo são da própria polícia ${ }^{13}$.

Com seu desaparecimento, aos familiares de Amarildo não foi garantido o direito de sepultá-lo - jus sepulchri. Houve inclusive a necessidade de declaração de sua morte presumida em face da não apresentação de seu cadáver ${ }^{14}$.

Cupis afirma que o cadáver é uma coisa que não pode ser objeto de negócio jurídico, fazendo parte das chamadas "coisas fora do comércio" (CUPIS, 2008, p. 98). Pontes de Miranda, reconhece autores que indicam que o cadáver poderia ser tanto uma coisa "extra commercium" como um "res nullius". Por sua vez, este autor também afirma que o cadáver seria uma "não-coisa" (PONTES DE MIRANDA, 1977, p. 12-13). No entanto, ele observa que em havendo a imemorialidade, a passagem do tempo, poderia fazer voltar certas partes ao comércio, como nos casos de esqueletos, múmias e ossos (PONTES DE MIRANDA, 1977, p. 14).

De Cupis afirma ainda que o destino normal de um cadáver é "a paz da sepultura" e, em casos mais raros, a doação para a realização de estudos científicos (PONTES DE MIRANDA, 1977, p. 99). Têm os parentes do morto o direito de escolherem a destinação do corpo $^{16}$ e as formas das cerimônias fúnebres sendo tal direito limitado por eventual ato de última vontade do morto (LINDON, 1983, p. 217). Surge aí o chamado "direito sobre o cadáver" (CHAVES, 1977, 162), "direito ao cadáver" (SZANIAWSKI, 1993, p. 303) ou ainda "direito ao corpo morto" (GUNTHER, 2008, p. 20) ${ }^{17}$. No entanto não seria este direito de escolha absoluto. A pessoa mais próxima do falecido poderia ser consultada ou até mesmo se opor "mostrando que não se justifica, in casu, a exceção aos costumes" (PONTES DE MIRANDA, 1977, p. 14).

Há situações de desentendimento entre os parentes para certas destinações pouco usuais. Em um caso recente, a filha de um falecido decidiu congelar o pai, na esperança de que no futuro ele pudesse ser ressuscitado e tivesse sua doença curada, enquanto os outros parentes queriam enterrá-lo. Segundo consta, o próprio falecido, em vida, manifestou sua

113 Caso Amarildo. Disponível em: <https://pt.wikipedia.org/wiki/Caso_Amarildo>. Acesso em: 10 jul 2015.

2 14Justiça declara morte presumida de Amarildo, desaparecido na Rocinha. Disponível em: <http://g1.globo.com/rio-de-janeiro/noticia/2014/o2/justica-declara-morte-presumida-deamarildo-desaparecido-desde-julho.html $>$. Acesso em: 10 jul 2015.

15 Nota-se a verdadeira genialidade de Pontes de Miranda quando, ao tratar sobre a questão envolvendo partes do corpo, entende que no caso de partes artificiais - próteses, dentes, ossos, etc. quando unidas ao corpo passam a fazer parte dele. Antes eram coisa, depois da união, viram corpo! 16Acerca das escolhas envolvendo o destino do corpo, a doutrina francesa aponta que a vontade do cônjuge sobrevivente deve prevalecer sobre a vontade de outros parentes quando presente sentimentos de afeição e harmonia entre os cônjuges. Neste sentido vide: LINDON, Raymond. Les droits de la personnalité. Paris: Dalloz, 1983, p. 217.

17 Dentro dos direitos da personalidade seria o chamado "direito ao corpo morto" que envolveria o "direito ao sepulcro, à cremação, à utilização científica, relativos ao transplante e ao culto religioso". 
ISSN 2316-2112

intenção de ser congelado, vontade que foi buscada arduamente pela filha, mesmo diante dos mais variados empecilhos ${ }^{18}$. Tal caso lembra, inegavelmente, a Antígona de Sófocles.

É possível ver, na doutrina da Lindon (1983), a importância existente na prevalência da vontade do parente mais próximo, principalmente, quando há "sentimentos de afeição e harmonia entre os cônjuges". Tal referência é de suma importância para este caso já que a questão foi decidida pelo Tribunal de Justiça do Rio de Janeiro. A decisão indicou que não havia nenhuma dúvida sobre a intenção do falecido em ter o corpo congelado e, da mesma forma, deveria ser levado em conta a intenção da filha, parente mais próxima e que mantinha relação de confiança com pai. Em função da importância do caso para este trabalho reproduzse aqui a parte da ementa do julgado que explicita os fatos:

1. A criogenia ou criopreservação consiste na preservação de cadáveres humanos em baixas temperaturas para eventual e futura reanimação e se insere dentre os avanços científicos que deram nova roupagem à ciência, rompendo com antigos paradigmas sociais, religiosos e morais. 2. Disputa acerca da destinação dos restos mortais do pai das litigantes, cujo desate não consiste na unificação da vontade das partes, mas sim na perquirição da real vontade do falecido. 3. Disposição de última vontade quanto à destinação de seu cadáver, que recai no rol dos direitos da personalidade constitucionalmente assegurados. Inexistência de testamento ou codicilo que não deve inviabilizar o cumprimento dos seus desígnios, sob pena de afronta ao princípio da dignidade da pessoa humana. 4. Em que pese a solenidade e o conservadorismo do direito sucessório pátrio, são reconhecidas formas excepcionais de testamento, como o particular, nuncupativo, marítimo e aeronáutico que prescindem das formalidades ordinárias e visam impedir que o indivíduo venha a falecer sem fazer prevalecer sua derradeira vontade. 5 . Os elementos constantes dos autos, em especial a prova documental, demonstram de forma inequívoca o desejo do falecido de ter o seu corpo congelado após a sua morte. 6 . Inafastável a aptidão da parenta mais próxima do falecido, com quem mantinha relação de afeto e confiança incondicionais, no caso, sua filha Lygia, para dizer sobre o melhor destino dos restos mortais, ou seja, aquele que melhor traduz suas convicções e desejos à época de seu óbito. 7. Ausência de previsão legal acerca do tema - criogenia - que, na forma do art. $4^{\circ}$ da LICC, autoriza a aplicação analógica das disposições existentes acerca da cremação, para a qual a Lei de Registros Públicos não estabeleceu forma especial para a manifestação de vontade. Precedentes deste Egrégio Tribunal. 8. Inexistência de paradigma jurisprudencial que não inviabiliza a pretensão diante da ausência de vedação legal e da demonstração de ser esta a disposição de última vontade do de cujus. Recurso provido. Vencida a Des. Ines da Trindade ${ }^{19}$.

18 LETA, Thamine. Jornal o Globo. Congelamento de corpo vira briga de família. 15 de Junho de 2012. Disponível em: <http://oglobo.globo.com/rio/congelamento-de-corpo-vira-briga-de-familia5209334>. Acesso em: 3 Jul. 2015. A filha gasta R\$ 27.000,00 por mês para manter o corpo congelado.

19TJ/RJ. 20 ${ }^{\text {a }}$ Câmara Cível. AC n. o057606-61.2012.8.19.0001. Rel. ${ }^{a}$ Des. $^{\text {a }}$ Flávia Romano de Rezende, j. em 25/12/2012. 
Em que pese a beleza da referida decisão, em sede de embargos infringentes, ela foi reformada com o argumento de que não havia a prova inequívoca da vontade do falecido em relação ao seu congelamento. Não se trouxe aos autos qualquer manifestação escrita e expressa da vontade do de cujus. Mesmo considerando, conforme se viu, que a doutrina aponta a possibilidade da prevalência da intenção do parente mais próximo, o Tribunal acabou por entender que o melhor e mais adequado, em função da dúvida, seria proceder ao enterro do falecido e não sua preservação criogênica. Os infringentes também invocaram o direito ao enterro - ou conforme a lição de Justino Silva, o jus sepulchri - que teria de ser preservado ${ }^{20}$.

A questão envolvendo a destinação do cadáver, em que pese a prevalência da vontade da família (SCHREIBER , 2014, p. 50) ${ }^{21}$, encontra exceções na ordem pública. Com isso, aquele que tenha sofrido um acidente ou morrido de forma violenta pode, mesmo a família sendo contrária, ter que passar por procedimentos e exames de necropsia (SCHREIBER , 2014, p. 50). O mesmo pode ser dito quando da situação envolvendo a morte em que há a suspeita de doenças altamente contagiosas, tudo em face do princípio do interesse público (SCHREIBER , 2014, p. 304), que neste caso prepondera sobre o interesse privado.

Ainda, há que se observar a vontade do morto no que se refere à doação de órgãos e a relação com o art. 14 do CC. O Conselho de Justiça Federal estabeleceu, nas Jornadas de Direito Civil, o enunciado n. $277^{22}$ que assim dispõe:

O art. 14 do Código Civil, ao afirmar a validade da disposição gratuita do próprio corpo, com objetivo científico ou altruístico, para depois da morte, determinou que a manifestação expressa do doador de órgãos em vida prevalece sobre a vontade dos familiares, portanto, a aplicação do art. $4^{o}$ da Lei n. 9.434/97 ficou restrita à hipótese de silêncio do potencial doador.

É certo que o art. 14 do CC não envolve apenas a doação de órgãos. Trata-se de dispor do próprio corpo, gratuitamente - ou seja, por meio de doação - com "objetivo científico, ou altruístico...". Além, portanto, da possibilidade de ser possível a doação do corpo para uma universidade de medicina, atualmente, existem outras figuras menos usuais. Uma das mais

20 TJ/RJ. $7^{\text {a }}$ Câmara Civel. EI n. 0057606 - 61.2012.8.19.0001. Rel. Des. Ricardo Couto de Castro, j. em 20/05/2014.

21 Segundo o autor, sobre a manifestação do falecido, que "a ausência dela não impede, contudo, a reconstrução da sua vontade, nem concede poder decisório aos seus familiares. Se e certo que, normalmente, o cônjuge e os parentes são as pessoas mais indicadas para relatar as intenções do morto, também é verdade que divergências não são incomuns no próprio seio da família." (SCHREIBER , 2014, p. 50)

22 Conselho da Justiça Federal. IV jornada de direito civil - Enunciados aprovados Enunciados ns. 272 a 396. Disponível em: <http://www.cjf.jus.br/CEJ-Coedi/jornadas-cej/enunciados-aprovados-dai-iii-iv-e-v-jornada-de-direito-civil/jornadas-de-direito-civil-enunciados-aprovados $>$. Acesso em: 10 jul 2015 .

Rua Silvério Manoel da Silva, 160 - Bairro Colinas - Cep.: 94940-243 | Cachoeirinha - RS | Tel/Fax. (51) 33961000 | e-mail: cesuca@cesuca.edu.br 
marcantes é a exposição "Human Bodies - Maravilhas do Corpo" "23. Trata-se de uma exposição que exibe corpos reais que passaram por um processo específico de plastificação para sua preservação. Os corpos são mostrados nus, alguns sem pele - deixando os músculos à mostra -, outros com partes retiradas com cortes específicos para demonstrar melhor a parte interna do corpo. A intenção é levar ao público o conhecimento sobre a anatomia humana.

A exposição chama bastante atenção e é frequentada, inclusive, por crianças. Evidentemente os corpos ali expostos contaram com a anuência das pessoas antes da morte. Alguns, segundo a notícia, até mesmo decidiram como gostariam de ser mostrados.

Situação semelhante foi tratada em uma corte francesa envolvendo a exposição " $A$ Corps Ouvert” em 2009 (SCHREIBER , 2014, p. 50). Lá, algumas entidades humanitárias conseguiram barrar a continuidade da exposição via a referida ação judicial. Schreiber, ao tratar sobre o caso, entende que, no Brasil, a interpretação do art. 14 não faz com que uma exposição dessa natureza possa ser considerada ilícita. $\mathrm{O}$ fundamento seria o seu caráter científico e instrutivo (SCHREIBER , 2014, p. 50). De qualquer forma, para afastar esta e outras situações de dúvida acerca da destinação do próprio corpo, o ideal é que a pessoa em vida realize manifestação escrita, expressa e inequívoca da sua vontade.

\section{A RESPONSABILIDADE CIVIL E OS DANOS DECORRENTES DE SITUAÇÕES FUNERÁRIAS}

A questão da responsabilidade civil envolvendo as relações funerárias enquadra-se no caso da responsabilidade contratual. Portanto, nesta parte específica do trabalho, foca-se apenas nesta forma de responsabilidade. Em tais casos, a responsabilidade aparece em função do descumprimento ou inadimplemento de uma obrigação contratual (MIRAGEM, 2015, p. 90). Ressalta-se, inclusive que é comum tais relações serem reguladas também pelo Código de Defesa do Consumidor (CDC).

Conforme preconiza o Código Civil (CC), em seu art. 927, aquele que comete ato ilícito e causa dano a outra pessoa, fica obrigado a reparar o dano. Note-se que código cita, exatamente, o causar dano a outrem. Independente da classificação jurídica do que seja o corpo de um parente falecido, é inegável que o tratamento inadequado aos restos mortais pode causar dano a alguém. Certamente não ao morto mas, sim, aos seus parentes. Em geral tais

23JUSTINO, Guilherme. Zero Hora. Exposição traz nove corpos humanos a Porto Alegre. 2 de Julho de 2015. Disponível em: <http://zh.clicrbs.com.br/rs/noticias/planetaciencia/noticia/2015/o7/exposicao-traz-nove-corpos-humanos-a-porto-alegre-4792959.html>. Acesso em 2 Jul. 2015 .

Rua Silvério Manoel da Silva, 160 - Bairro Colinas - Cep.: 94940-243 | Cachoeirinha - RS | Tel/Fax. (51) 33961000 | e-mail: cesuca@cesuca.edu.br 
danos serão de ordem extrapatrimonial. Todavia há situações de dano patrimonial envolvendo situações funerárias. Aquele que danifica túmulo ou mausoléu, certamente, além de ter que responder por dano moral terá que responder também pelo prejuízo material.

Aquele que enterra um ente querido em um cemitério, em regra, adere a um contrato. Os contratos funerários, principalmente aqueles envolvendo o enterro de um corpo, podem ser considerados como contrato atípicos. Envolvem, basicamente, elementos de compra e venda, locação e prestação de serviços (LORENZETTI, 1999, p. 382). Contrata-se a possibilidade de usar um prédio por meio do pagamento permanente que envolve a "prestação de serviços de administração e cuidado" visando manter os restos mortais do falecido (LORENZETTI, 1999, p. 382-383).

Mas é necessário tratar de forma diferente o contrato de prestação de serviços funerários (transporte e preparação do cadáver) e o contrato com o cemitério que envolve o enterro (a inumação ${ }^{24}$ ) e a manutenção do cadáver em suas dependências. $O$ último caso pode envolver tanto um vínculo perpétuo ou temporário o que toca na frequência das prestações (e até mesmo na possibilidade de renovação) (LORENZETTI, 1999, p. 384). De outra forma, também são diferentes os contratos que envolvem o pagamento antecipado de planos funerários. Aqueles envolvem a prestação de serviços imediatos, enquanto estes são contratos cativos de longa duração "que vinculam o fornecedor e um grupo (familiar) de consumidores por vários anos, até que ocorram os falecimentos[...]" (MARQUES, 2014, p. 549). Não há dúvida, em todos esses casos, que se tratam de contratos de consumo e que devem contar com toda a proteção que se extrai do CDC (MARQUES, 2014, p. 550). Na observação de Marques trata-se, talvez, do último contrato de consumo de alguém.

Mesmo que se trate de relações que devam observar as regras do CDC, evidentemente, não se trata de situações corriqueiras e comuns na vida das pessoas. Não se comparar, por exemplo, a contratação de serviços funerários com a compra de um eletrodoméstico ou com o conserto de um automóvel. Trata-se de serviços especiais, que envolvem um momento extremamente peculiar e delicado da vida das pessoas. Este visa o preparo do parente falecido para uma cerimônia que, como se viu na primeira parte deste artigo, remonta os primórdios da sociedade organizada. A obra de Sófocles serve para mostrar até onde alguém pode ir para garantir um funeral para seus parentes. Aqueles que já passaram por tal situação sabem do sentimento de desorientação que abate os parentes do falecido. São momentos de extrema dor, preocupação e sentimento de impotência. Não há dúvidas de que se pode considerar que os parentes do recém-falecido encontram-se em um estado de vulnerabilidade ampliada. Dificilmente alguém está absolutamente preparado para lidar com tais situações. São, como se disse, situações especiais que requerem, por parte dos fornecedores de tais serviços, um tratamento igualmente especial. Não se deve perder de vista, ao mesmo tempo, que nos casos

24 Inumação, segundo o dicionario Aulete é a "Ação ou resultado de inumar; enterro; sepultamento". Seu antônimo é a exumação. 
em que os parentes do morto são idosos, nota-se aí uma "vulnerabilidade especial do consumidor fraco" (MARQUES, 2014, p. 382).

Outro assunto bastante importante relativo aos serviços funerários diz respeito à proteção dos direitos da pessoa que morreu. Como o morto não possui mais personalidade, a proteção de sua imagem, por exemplo, é transferida aos parentes (cônjuge, ascendentes ou descendentes) conforme os art. 12 e 20 do CC. Isso não quer dizer que se transmitem os direitos da personalidade, ideia que se rechaça diante da característica marcante da intransmissibilidade de tais direitos, de acordo com o art. 11 do CC. O que se transmite aos parentes, portanto, é a "legitimação processual para a defesa de tais direitos" (BELTRÃO, 2014, p. 126), tendo em vista que, naturalmente, o morto não pode, ele próprio, exercer seus direitos.

É com a morte que nasce o direito dos parentes defenderem os direitos do falecido. Isso ocorre em função da natural relação entre o morto e seus parentes em atenção também aos valores familiares. Respeita-se não apenas o morto mas a própria dignidade familiar. De forma geral, está-se a proteger os reflexos da personalidade "como a memória, a imagem, a honra do defunto - [que] se projetam para além da morte em outras pessoas" (TEPEDINO, 2011, p. V-VI). Todavia, tal disposição não deve ser confundida com o art. 943 do CC, que permite serem transmitidos o direito de pedir reparação em função de dano ocorrido quando o morto ainda era vivo (TEPEDINO, 2011, p. V-VI).

Entende-se, contudo, que deve ser restrita a interpretação, principalmente do art. 12 do $\mathrm{CC}$, envolvendo a possibilidade de um parente exigir que cesse a ofensa dos direitos da personalidade de um parente morto. Deve ser notado que há certos direitos que não poderiam ser reclamados pelos parentes em relação ao cadáver como, por exemplo, a liberdade e a própria vida (BELTRÃO, 2014, p. 129-130), esta última, que já se foi. Não se defende que o morto, que não tem mais personalidade ${ }^{25}$, poderia ter seus direitos ofendidos. Todavia seria incompatível com o ordenamento e com os valores gerais da personalidade, que se permitissem que a imagem, a honra ou a intimidade daqueles que se foram, possam ser violados. Preservam-se "os valores da personalidade humana" (BELTRÃO, 2014, p. 129131) como um todo, de forma ampla para todos os seres humanos, inclusive daqueles que se foram. É essa também a posição de Meireles ao afirmar que, com a morte, perdem-se os aspectos da personalidade como a capacidade. Todavia restariam a necessidade de proteger a personalidade enquanto valor que deve ser protegido pelo ordenamento (MEIRELES, 2009, p. 162). Protege-se também a própria sociedade. É nesse sentido que se irá permitir que os parentes possam defender a memoria daquele que faleceu.

25 Na observação de Pontes de Miranda: "Morto não tem direitos; os vivos os tem [...] o direito é organização da vida social dos vivos”. PONTES DE MIRANDA, 1977, p. 14. 
ISSN 2316-2112

Por outro lado há certos direitos que passam a existir apenas com a morte. Trata-se da proteção geral ao cadáver, a proteção da sepultura, as questões relativas à destinação do corpo, dentre outros (GARCIA, 2007, p. 108).

Existiria, assim, a proteção à memória do morto (GARCIA, 2007, p. 133) que os parentes têm o direito de tutelar de forma autônoma, mesmo que estes - os parentes - não sofram lesão à própria personalidade (GARCIA, 2007, p. 134). Essa diferenciação entre a ofensa à memória do morto e a ofensa aos direitos da personalidade dos parentes pelo mau tratamento do cadáver é relevante. Embora ambas ensejam indenização por danos morais, seu fundamento é diferente. Pode a memória do morto ser ofendida sem que, necessariamente, sejam ofendidos os direitos da personalidade dos parentes. Trata-se, no caso da defesa da memória do morto, de um direito subjetivo dos parentes que não se confunde com o direito subjetivo que tinha o morto quando era vivo (SILVA, 1993, p. 8).

Sobre a questão da manipulação indevida de restos mortais cabe a citação de obra seminal sobre danos morais. Trata-se do livro "O Dano Moral no Direito Brasileiro" de Ávio Brasil. Como se sabe, nem sempre foi pacífica a questão da indenização por danos morais e a obra de Brasil importa na sua defesa em 1944. Nesta obra o autor trata, entre outras questões, sobre o dano moral envolvendo exatamente o desvio de restos mortais. Trata ele de uma situação onde os restos mortais da filha dos autores foi retirado do carneiro do cemitério antes do prazo estabelecido no contrato (BRASIL, 1944, p. 139). O curioso é a forma de arbitramento do dano moral. Utilizou-se o art. 1547 do CC de 1916 onde constava que "se este não puder provar prejuizo material, pagar-lhe-á o ofensor o dobro da multa no grão máximo da pena criminal respectiva"(BRASIL, 1944, p. 143). Invocou-se o referido instituto - aplicável aos casos de injúria ou calúnia - como balizador para a atividade de arbitramento, por meio da analogia, na falta de um critério mais específico (BRASIL, 1944, p. 144).

Os parentes também podem solicitar a proibição da publicação das imagens de um parente morto que possam ter sido realizadas. Aí, merece atenção o fenômeno de massificação da informática e o intenso compartilhamento de conteúdos em redes sociais. Com a massificação do uso de telefones móveis dotados de câmeras passa a ser cada vez mais natural que as pessoas fotografem todo o tipo de situações, inclusive aquelas que deveriam permanecer não retratadas.

Não se trata de proteger a intimidade do falecido, que não tem mais personalidade, mas sim, proteger sua imagem póstuma. Tal conduta encontra-se, igualmente, balizada no Código de Ética e Autoregulamentação do setor funerário em seu art. 11:

O Diretor Funerário manterá sigilo profissional nos assuntos particulares de interesse daqueles que solicitarem seus serviços. Não prestará nem divulgará qualquer informação, imagem ou fotografia, que tenha relação com o atendimento funerário, salvo quando autorizado pela família e 
ressalvada a sua obrigação de divulgar informações exigíveis nos termos da lei.

Situação recente e que causou consternação envolveu um jovem cantor sertanejo, morto em um acidente de carro em junho de $2015^{26}$. Durante a preparação do corpo para o enterro, os funcionários da clínica contratada pela família tiraram fotos e gravaram um vídeo da realização da atividade. Ato contínuo, o material foi postado na Internet em flagrante desrespeito à imagem do morto causando imensa comoção entre os admiradores do cantor ${ }^{27}$. Tal caso envolve a clara violação do dever de sigilo e confidencialidade daqueles que preparam corpos para as cerimônias funerárias (a chamada tanatopraxia ou embalsamamento). É evidente que a referida atividade, por lidar com o corpo humano, causa repulsa e desconforto na maioria das pessoas e, portanto, deve ser ato reservado não sendo admitida qualquer reprodução do ato.

Neste caso em especial, foi acionado o poder judiciário, para que as referidas fotografias e vídeos fossem retiradas da internet:

O juiz da $3^{a}$ Vara de Família e Sucessões do Tribunal de Justiça de Goiás (TJGO) determinou a retirada das fotos e dos vídeos do cantor Cristiano Araújo sendo preparado para o velório.

$[\ldots]$

O juiz Willian Fabian considerou que "a publicação das imagens de necrópsia e da preparação de cadáver, ocorrida concomitantemente ao velório e sepultamento do cantor Cristiano de Melo Araújo, além de revelarem inquietante morbidez, apresenta-se extremamente desrespeitosa ao sentimento de luto das famílias dos vitimados no trágico acidente que ceifou-lhes as vidas, ferindo frontalmente o direito constitucional da intimidade, insculpido no artigo 5o, inciso $X$, da Constituição Federal Brasileira", consta da cautelar. A medida deve ser cumprida imediatamente pelos escritórios de representação do Facebook e do Google no Brasil. A multa por descumprimento é de $R \$ 10$ mil por dia. Na manhã desta sexta-feira (26/6), duas pessoas foram indiciadas pela Polícia de Goiás em conexão com o vazamento das imagens. [...] Os suspeitos podem responder na Justiça por crime de vilipendiar cadáver (desrespeito ao corpo). A pena vai de um a três anos de prisão. ${ }^{28}$

Há, salvo engano, em relação ao caso acima, exceções à reserva do ato envolvendo a manipulação do corpo. A primeira envolve os casos onde a pessoa em vida permite que seu

26 Advogados vão apurar imagens de Cristiano Araújo feitas após morte Disponível em: <http://g1.globo.com/goias/musica/noticia/2015/o6/advogados-vao-apurar-imagens-de-cristianoaraujo-feitas-apos-morte.html>. Acesso em: 10 jul 2015.

27 R7. Funerária e hospital investigam vazamento de imagens do corpo de Cristiano Araújo. 25 de Junho de2015. Disponível em: <http://noticias.r7.com/cidades/funeraria-e-hospital-investigamvazamento-de-imagens-do-corpo-de-cristiano-araujo-25062015>. Acesso em: 2 Jul. 2015.

28Juiz determina retirada de fotos e vídeos do corpo de Cristiano Araújo Disponível em: <http://www.diariodepernambuco.com.br/app/noticia/viver/2015/o6/26/internas_viver,583337/jui z-determina-retirada-de-fotos-e-videos-do-corpo-de-cristiano-araujo.shtml >. Acesso em: 10 jul 2015. 
corpo seja utilizado para estudos médicos, situação que permitiria que a manipulação do corpo fosse assistida por mais pessoas. Mesmo assim, no último caso, há que se ter cuidado para não divulgar eventuais imagens de atos realizados, por exemplo, em uma faculdade de medicina, sob pena de ofender a honra dos parentes do morto. Já o segundo caso envolveria aquelas situações de morte violenta pelo cometimento de crimes, onde a polícia, para a constituição de provas no inquérito policial, fotografa o corpo morto (SZANIAWSKI, 1993, p. 305). Trata-se do direito maior à produção de provas. Em tais casos, destaca-se, tais fotografias poderiam ser utilizadas apenas e estritamente para fins de inquérito policial. De outro lado, ainda, a visualização de tais fotos ou do próprio corpo morto poderia ser realizada, ainda, para fins de reconhecimento de pessoa morta e não identificada (SZANIAWSKI, 1993, p. 306). Outras ponderações ainda poderiam ser feitas como, por exemplo, a possibilidade de alguém solicitar a exumação de um cadáver para a verificação de eventual grau de parentesco, conforme aponta Beltrão (2014, p. 130). Mesmo assim, de acordo com a jurisprudência do TJ/RS tal medida é excepcional e apenas pode ocorrer "em situação excepcional, quando inexistem outros meios robustos de prova" ${ }^{, 29}$. Se outros herdeiros, por exemplo, recusarem-se a fazer exame em ação de investigação de paternidade seria possível a exumação dos restos mortais para a constituição de prova ${ }^{30}$.

Em outro caso, o Estado do Rio Grande do Sul foi responsabilizado, reconhecendo a responsabilidade do estado por atos de seus agentes envolvendo as relações funerárias (SILVA, 1990, p. 27). Em um acidente fatal onde as vítimas ficaram desfiguradas o policial que primeiro atendeu a ocorrência fotografou os corpos e publicou as fotos na Internet. A decisão do $\mathrm{TJ} / \mathrm{RS}$, reconhecendo a responsabilidade objetiva do Estado, considerou a publicação como um ato ilícito, arbitrando indenização de $\mathrm{R} \$ 12.000,00$. Fato curioso deste julgado é que, embora o inquérito publico contivesse as fotos, reconheceu-se que esta publicidade não autoriza que se publiquem as fotos na Internet. Seria um absoluto desvio da finalidade daquela publicidade, e consequente abuso de direito, que atingiria a honra dos parentes do falecido ${ }^{31}$.

Há diversos casos em que se concederam indenizações aos parentes de um falecido pelo tratamento dado ao cadáver, assunto instigante para ser tratado no âmbito da responsabilidade civil e do direito do consumidor. Já se decidiu que é ato ilícito passível de indenização: a falta de cuidado de cemitérios ao lidarem com restos mortais ${ }^{32}$; a perda de cadáver pelo $\mathrm{IML}^{33}$; a troca de cadáver $^{34}$; a demora do IML em liberar o corpo ${ }^{35}$; a má-

29 TJ/RS. $7^{\text {a }}$ Câmara Cível. AI n. 70063786461. Rel. ${ }^{a}$ Des. $^{a}$ Liselena Schifino Robles Ribeir, j. 04/03/2015.

30 TJ/MG. $1^{\text {a }}$ Câmara Cível. AI n. 10028080178859001. Rel. Des. Alberto Vilas Boas, j. 13/05/2014. 31 TJ/RS. $9^{\text {a }}$ Câmara Cível. AC n. 70048210926. Rel. ${ }^{a}$ Des. $^{\text {a }}$ Iris Helena Medeiros Nogueira. J. em 18/07/2012.

32 TJ/RS. $5^{\text {a }}$ Câmara Cível. AC n. 70052886405. Rel. ${ }^{a}$ Des. ${ }^{a}$ Isabel Dias Almeida. J. em 27/03/2013. 33 STJ. $4^{\text {a }}$ Turma. REsp. n. 1.351.105 - SP. Rel. Min. Raul Araújo. J. em 06/06/2013.

34 TJ/RS. 10 ${ }^{\text {a }}$ Câmara Cível. AC n. 70048365852. Rel. Des. Jorge Alberto Schreiner Pestana. J. em 23/05/2013 e TJ/RS. 6a Câmara Cível. AC n. 70048648729. Rel. Des. Niwton Carpes da Silva. J. em 29/08/2013.

35 TJ/RS. $9^{\text {a }}$ Câmara Cível. AC n. 70058271073 . Rel. ${ }^{a}$ Des. ${ }^{a}$ Iris Helena Medeiros Nogueira. J. em $12 / 03 / 2014$.

Rua Silvério Manoel da Silva, 160 - Bairro Colinas - Cep.: 94940-243 | Cachoeirinha - RS | Tel/Fax. (51) 33961000 | e-mail: cesuca@cesuca.edu.br 
prestação de serviços de cemitério que retira o caixão do túmulo e deixa o corpo em decomposição exposto permitindo que os parentes assim o vejam ${ }^{36}$; o enterro de filho como indigente $^{37}$; a entrega feita pela funerária do corpo em estado de putrefação inviabilizando assim o velório (caso em que a funerária não zelou em fazer o transporte adequado de um Estado para o outro) ${ }^{38}$; a demora do hospital em informar a morte de parente ${ }^{39}$; o enterro de pessoa estranha em jazigo familiar ${ }^{40}$; a exumação não autorizada pela família ${ }^{41}$; a troca de cadáveres pela polícia que culminou na necessidade de realizar um segundo enterro pela família que não notara a troca no primeiro ${ }^{42}$.

A jurisprudência entende, também, que há um dever geral de cuidado da sepultura e do cemitério em si. Não pode, mesmo nos casos de cemitérios públicos, deixar-se o sítio (a necrópole) em questão sem vigilância permitindo, assim, que terceiros depredem as sepulturas. Em um caso específico, o município de Porto Alegre teve que responder pela falha no dever de cuidado das sepulturas, arcando com indenização material relacionada ao conserto e reposição de ornamentos fúnebres ${ }^{43}$. $\mathrm{O}$ mesmo também pode ser dito do cemitério que retira os restos mortais de um familiar do túmulo sem autorização dos familiares e depois os extravia. Em tal situação foi arbitrada a indenização de $\mathrm{R} \$ 8.000,00^{44}$. Em caso semelhante a indenização foi de $\mathrm{R} \$ 4.000,00$ para apenas a remoção dos restos mortais sem autorização, sem a ocorrência do extravio ${ }^{45}$.

Todos os casos, mesmo apenas com a informação breve do ilícito, causam repulsa. Todavia há casos mais paradigmáticos do que outros. Um dos casos mais absurdos encontrados sobre o tema envolveu o vazamento de fluídos corporais do morto durante o velório, causando um odor insuportável e inviabilizando o próprio velório, cujo objetivo é buscar trazer aos familiares um pouco de conforto pela perda do ente querido. Os parentes tiveram, inclusive, que realizar a limpeza do local. Fica evidente o dano moral sofrido em tal

36 TJ/RJ. 21 a Câmara Cível. AC n. 347937-13.2009.8.19.0001. Rel. Des. Pedro Raguenet. J. em 05/11/2013.

37 TJ/SP. $1^{\text {a }}$ Câmara de Direito Público. AC n. 9133531-20.2009.8.26.oooo. Rel. Des. Castilho Barbosa. J. em 28/02/2013.

38 TJ/PR. $10^{\text {a }}$ Câmara Cível. AC n. 914.155-7. Rel. ${ }^{a}$ Des. ${ }^{a}$ Denise Antunes. J. em 11/10/2012.

39TJ/SP. 6 ${ }^{\text {a }}$ Câmara de Direito Privado. AC n. 0049497-21.2011.8.26.0576. Rel. Des. Francisco Loureiro. J. em 25/07/2013.

40TJ/RS. 9a Câmara Cível. AC n. 70054937644. Rel. Des. Tasso Caubi Soares Delabary. J. em 05/09/2013.

41TJ/SP. 1 ${ }^{\mathrm{a}}$ Câmara de Direito Público. AC n. 0079604-08.2009.8.26.0224. Rel. ${ }^{\mathrm{a}}$ Des. $^{\mathrm{a}}$ Regina Capistrano. J. em 18/01/2011.

42TJ/AP; Câmara Única. AC. n. 145703. Rel. Des. Carmo Antônio. J. em 10/o2/2004.

43TJ/RS. $5^{\text {a }}$ Câmara Cível. AC n. 70057090342. Rel. ${ }^{a}$ Des. ${ }^{a}$ Isabel Dias Almeida. J. em 10/12/2014.

44 TJ/RS. 9 a Câmara Cível. AC n. 70058993643. Rel. Des. Miguel Agnelo da Silva. J. em 24/09/2014.

45 TJ/RS. $10^{\text {a }}$ Câmara Cível. AC n. 70057238339. Rel. Des. Paulo Roberto Lessa Franz. J. em 29/05/2014.

Rua Silvério Manoel da Silva, 160 - Bairro Colinas - Cep.: 94940-243 | Cachoeirinha - RS | Tel/Fax. (51) 33961000 | e-mail: cesuca@cesuca.edu.br 
ocasião diante do sofrimento, da dor e do constrangimento extremos dos parentes que se viram obrigados a passar por tal situação ${ }^{46}$.

Por fim, deve ser lembrado que a municipalidade impõe regras específicas para os cemitérios públicos sob seu controle. Na cidade de Porto Alegre, por exemplo, há o Decreto 12.330/1999, que Aprova o Regulamento dos Cemitérios Municipais. A mesma cidade estatui a lei 3.433/1970, que "Estabelece as condições técnicas para a implantação de cemitérios no Município". Entre os cuidados estabelecidos por esta lei há a obrigação de que os cemitérios mantenham faixas verdes de isolamento para "propiciar o bloqueio visual das áreas de sepultamento a partir dos logradouros e imóveis circunvizinhos" (art. $6^{\circ}, \S 2^{\circ}$ ). São definidas também, até mesmo, a estrutura do cemitério com a estipulação de áreas e funções necessárias para essas atividades. De forma geral, como se vê, tais regras visam regular questões administrativas, organizacionais e até mesmo de saúde pública. De outro lado, deve ser citado o Código de Ética e Autorregulamentação do Setor Funerário (CEARF), organizado pela Associação Brasileira de Empresas e Diretores Funerários - ABREDIF. O principal objetivo deste Código de Ética, segundo seu art. $1^{\circ}$, é "a regulamentação da atividade funerária em consonância com a legislação vigente e a obediência aos preceitos éticos e morais da sociedade, de forma a promover o desenvolvimento do setor, a valorização profissional e a busca do entendimento" ${ }^{47}$.

\section{CONSIDERAÇÕES FINAIS}

Para muito além da discussão entre direito natural e direito posto, é possível extrair da obra Antígona lições e pontos de partida para outros temas. Objetivou-se aqui abordar a questão do cadáver, sua destinação e a responsabilidade civil por ilícito envolvendo o mau tratamento do corpo. Toda a doutrina dos direitos da personalidade - com a análise de um direito sui generis sobre o cadáver - e a análise do conceito de jus sepulchri foram importantes para o desenvolvimento do trabalho. Além do mais, é importante a consideração

46TJ/RS. 10 a Câmara Cível. AC n. 70061399366. Rel. Des. Jorge Alberto Schreiner Pestana. J. em 02/04/2015. A decisão apontou que houve falha na informação da funerária ao não indicar os procedimentos suplementários necessários que deveriam ter sido contratados (caixão diferenciado e realização de preparo do corpo, a chamada, tanatopraxia). Infelizmente, no caso, a indenização pelos danos sofridos não ultrapassou $\mathrm{R} \$ 5.000,00$ o que se afigura, na visão destes autores, muito pequena em função do sofrimento e constrangimento.

47 Conforme indicação de MARQUES, Cláudia Lima. Ibidem, p. 549. O referido código pode ser encontrado em: <http://www.sindinef.com.br/juridico-codigo-de-eticadetalhes.php?codigoEtica $=1+$ CoDIGo+DE+ETICA+E+AUTo-

REGULAMENTACAo+Do+SEToR+FUNERARIo>. Acesso em 10 Jun. 2015. 
da vontade do falecido quando da destinação de seu corpo, ocorrendo, como seu viu, situações complexas levadas ao judiciário que precisou decidir sobre a destinação de um cadáver (no caso da Criogenia).

Foi possível ver que não são incomuns situações da mais absoluta negligência dos prestadores de serviços funerários e cemitérios e que causam profunda dor e desconforto aos parentes do falecido. Como se disse, é natural que as pessoas tenham que providenciar o preparo e o enterro dos corpos de seus parentes. Todavia, mesmo sendo natural, as pessoas encontram-se em estado de vulnerabilidade ampliada, o que enseja o dever de tais fornecedores a atuarem com o maior zelo possível. O desleixo e a negligência devem ser evitados visto que se trata de um corpo humano, que possui uma história e uma trajetória, teve uma personalidade única e deixa famílias, amigos e um legado, cuja prestação de serviços funerários não pode macular.

\section{REFERÊNCIAS BIBLIOGRÁFICAS}

ALBORNOZ, Suzana. O exemplo de antígona: ética, educação e utopia. Porto Alegre: Moviemnto, 1999.

ALVES, Marcelo. Antígona e o direito. Curitiba: Juruá, 2007.

ARISTÓTELES. Poética. 2 ed. São Paulo: Abril, 1984.

BELTRÃO, Silvio Romero. Direitos da Personalidade. São Paulo: Atlas, 2014,

BRASIL, Ávio. O dano moral, no direito brasileiro. Rio de Janeiro: Livraria Jacinto, 1944,

BUTLER, Judith, O clamor de antígona: parentesco entre a vida e a morte. Florianópolis:

UFSC, 2014.

BUTLER, Judith. Deshacer el género. Barcelona: Paidós, 2006,

CHAVES, Antônio. Direitos à vida, ao próprio corpo e às partes do mesmo (transplantes). Esterilizações e operações cirúrgicas para "mudança de sexo". Direito ao cadáver e a partes do mesmo. Revista de Informação Legislativa. n. 55, p. 125-168, jul.-set./1977.

COULANGES, Fustel de. A cidade antiga. São Paulo: Martins Fontes, 1981, CUPIS, Adriano de. Os Direitos da Personalidade. São Paulo: Quórum, 2008,

GARCIA, Éneas Costa. Direito Geral da Personalidade no Sistema Jurídico Brasileiro. São Paulo: Juarez de Oliveira, 2007,

GUNTHER, Luiz Eduardo. Os direitos da personalidade e suas repercussões na atividade empresarial. Revista do TRT 9 ${ }^{\circ}$, n. 60, jan./ jun. 2008.

HOLANDA, Sérgio Buarque de. Raízes do Brasil. 26ª ed. São Paulo: Companhia das Letras, 1995.

JUSTINIANUS, Flavius Petrus Sabbatius. Institutas do Imperador Justiniano. Bauru: Edipro, 2001.

LACAN, Jacques. O seminário: A ética da psicanálise. V. 7. $2^{\mathrm{a}}$ ed. Rio de Janeiro: Zahar, 2008.

LINDON, Raymond. Les droits de la personnalité. Paris: Dalloz, 1983.

LORENZETTI, Ricardo Luis. Tratado de los Contratos. Tomo I. Buenos Aires: RubinzalCulzoni, 1999

MAGNO, Albino Pereira. Mitologia. Lisboa: J. Rodrigues, [19--]. 
MARINHO, Inezil Penna. Interpretação de "antígona " à luz do direito natural. Rio de Janeiro: Cadernos da Serra. 1980. 83 p. (Coleção Imbuí - Ensaios e Crônicas n. 5)

MARQUES, Cláudia Lima. Contratos no Código de Defesa do Consumidor: O novo regime das relações contratuais. $7^{\mathrm{a}}$ ed., São Paulo: Thomson Reuters, 2014.

MEIRELES, Rose Melo Vencelau. Autonomia Privada e Dignidade Humana. Rio de Janeiro: Renovar, 2009.

MIRAGEM, Bruno Nubens Barbosa. Direito Civil: Responsabilidade Civil. São Paulo: Saraiva, 2015.

MORIN, Edgar. El Método: 6. Ética. Madrid: Cátedra, 2006.

PANDOLFO, Maria do Carmos Peixonto. Ser ou não ser Antígona: uma leitura de 'Antigone'. Rio de Janeiro: Imago, 1977.

PONTES DE MIRANDA, Francisco Cavalcanti. Tratado de Direito Privado. Tomo II. São Paulo: RT, 1977.

PONTES DE MIRANDA, Francisco Cavalcanti. Tratado de Direito Privado. Tomo V. Rio de Janeiro: Borsoi, 1970,

REALE, Miguel. Filosofia do Direito. 19a ed. São Paulo: Saraiva, 1999.

SAVIGNY, Friedrich Carl von. Sistema del derecho romano actual. Trad. M. Ch. Guenoux. Madrid: Góngora y Compañia, 1878, v. 1.

SCHREIBER, Anderson. Direitos da Personalidade. $3^{\mathrm{a}}$ ed. Rev. e Atual. São Paulo: Atlas, 2014.

SILVA, Edson Ferreira. Direitos de personalidade: os direitos de personalidade são inatos? Revista dos Tribunais, v. 624, Ago./1993, (versão digital).

SILVA, Justino Adriano F. da. Alguns aspectos da responsabilidade civil do poder público em matéria de direito funerário. Revista Estudos Jurídicos v. 23, n. 57, p. 19-44, Jan.-Abril/1990.

SÓFOCLES, Antígona. Porto Alegre: L\&PM, 2014.

SÓFOCLES. Antígona. In: SÓFOCLES. Trilogia Tebana. Edição e-book. São Paulo: Zahar, 1990.

SZANIAWSKI, Elimar. Direitos de personalidade e sua tutela. São Paulo: RT, 1993.

TEPEDINO, Gustavo. Editorial: Tutela da personalidade após a morte. V. 46, p. V-VI, Abr.Jun./2011.

TORRANCE, Isabelle. Antigone and her Brother: What Sort of Special Relationship? In: WILMER, S.E; ZUKAUSKAITE, Audrone (ed.) Interrogating Antigone in Postmodern Philosphy and Criticism. Oxford: Oxford University Press, 2010.

VORSATZ, Ingrid. Antígona e a ética trágica da psicanálise. Rio de Janeiro: Zahar, 2013.

\section{Julgados}

BRASIL. STJ. $4^{\text {a }}$ Turma. REsp. n. 1.351.105 - SP. Rel. Min. Raul Araújo. J. em 06/06/2013 e

AMAPÁ. TJ/AP; Câmara Única. AC. n. 145703. Rel. Des. Carmo Antônio. J. em 10/02/2004. MINAS GERAIS. TJ/MG. $1^{a}$ Câmara Cível. AI n. 10028080178859001. Rel. Des. Alberto Vilas Boas, j. 13/05/2014.

PARANÁ. TJ/PR. 10 Câmara Cível. AC n. 914.155-7. Rel. ${ }^{a}$ Des. ${ }^{a}$ Denise Antunes. J. em $11 / 10 / 2012$.

RIO DE JANEIRO. TJ/RJ. 21 a Câmara Cível. AC n. 347937-13.2009.8.19.0001. Rel. Des. Pedro Raguenet. J. em 05/11/2013.

RIO DE JANEIRO. TJ/RJ. 20ª Câmara Cível. AC n. 0057606-61.2012.8.19.0001. Rel. ${ }^{\mathrm{a}}$ Des. ${ }^{\mathrm{a}}$ 
Flávia Romano de Rezende, j. em 25/12/2012.

RIO GRANDE DO SUL. TJ/RS. 10a Câmara Cível. AC n. 70048365852. Rel. Des. Jorge Alberto Schreiner Pestana. J. em 23/05/2013

RIO GRANDE DO SUL. TJ/RS. 10ª Câmara Cível. AC n. 70057238339. Rel. Des. Paulo Roberto Lessa Franz. J. em 29/05/2014.

RIO GRANDE DO SUL. TJ/RS. 10ª Câmara Cível. AC n. 70061399366. Rel. Des. Jorge Alberto Schreiner Pestana. J. em 02/04/2015.

RIO GRANDE DO SUL. TJ/RS. 5 ${ }^{\text {a }}$ Câmara Cível. AC n. 70052886405. Rel. ${ }^{a}$ Des. $^{a}$ Isabel Dias Almeida. J. em 27/03/2013.

RIO GRANDE DO SUL. TJ/RS. 5ª Câmara Cível. AC n. 70057090342. Rel. ${ }^{a}$ Des. $^{\text {a }}$ Isabel Dias Almeida. J. em 10/12/2014.

RIO GRANDE DO SUL. TJ/RS. 6 ${ }^{a}$ Câmara Cível. AC n. 70048648729. Rel. Des. Niwton Carpes da Silva. J. em 29/08/2013.

RIO GRANDE DO SUL. TJ/RS. 7 ${ }^{\mathrm{a}}$ Câmara Cível. AI n. 70063786461. Rel. ${ }^{\mathrm{a}}$ Des. ${ }^{\mathrm{a}}$ Liselena Schifino Robles Ribeir, j. 04/03/2015.

RIO GRANDE DO SUL. TJ/RS. 9 ${ }^{a}$ Câmara Cível. AC n. 70058271073. Rel. ${ }^{a}$ Des. $^{\text {a }}$ Iris Helena Medeiros Nogueira. J. em 12/03/2014.

RIO GRANDE DO SUL. TJ/RS. 9a Câmara Cível. AC n. 70048210926. Rel. ${ }^{a}$ Des. $^{\text {a }}$ Iris Helena Medeiros Nogueira. J. em 18/07/2012.

RIO GRANDE DO SUL. TJ/RS. 9a Câmara Cível. AC n. 70054937644. Rel. Des. Tasso Caubi Soares Delabary. J. em 05/09/2013.

RIO GRANDE DO SUL. TJ/RS. 9ª Câmara Cível. AC n. 70058993643. Rel. Des. Miguel Agnelo da Silva. J. em 24/09/2014.

SÃO PAULO. TJ/SP. $1^{\text {a }}$ Câmara de Direito Público. AC n. 0079604-08.2009.8.26.0224. Rel. ${ }^{\mathrm{a}}$ Des. ${ }^{a}$ Regina Capistrano. J. em 18/01/2011.

SÃO PAULO. TJ/SP. 1ª Câmara de Direito Público. AC n. 9133531-20.2009.8.26.0000. Rel. Des. Castilho Barbosa. J. em 28/02/2013.

SÃO PAULO. TJ/SP. $6^{a}$ Câmara de Direito Privado. AC n. 0049497-21.2011.8.26.0576. Rel. Des. Francisco Loureiro. J. em 25/07/2013.

Conselho da Justiça Federal. IV Jornada de Direito Civil - Enunciados aprovados: 272 a 396. Disponível em: <http://www.cjf.jus.br/CEJ-Coedi/jornadas-cej/enunciados-aprovados-da-i-iiiiv-e-v-jornada-de-direito-civil/jornadas-de-direito-civil-enunciados-aprovados $>$. Acesso em: 10 jul 2015.

\section{Notícias}

Advogados vão apurar imagens de Cristiano Araújo feitas após morte Disponível em: $<$ http://g1.globo.com/goias/musica/noticia/2015/06/advogados-vao-apurar-imagens-decristiano-araujo-feitas-apos-morte.html>. Acesso em: 10 jul 2015.

Caso Amarildo. Disponível em: <https://pt.wikipedia.org/wiki/Caso_Amarildo $>$. Acesso em: 10 jul 2015.

Juiz determina retirada de fotos e vídeos do corpo de Cristiano Araújo Disponível em: $<$ http://www.diariodepernambuco.com.br/app/noticia/viver/2015/06/26/internas_viver,583337 /juiz-determina-retirada-de-fotos-e-videos-do-corpo-de-cristiano-araujo.shtml $>$. Acesso em: 10 jul 2015.

Justiça declara morte presumida de Amarildo, desaparecido na Rocinha. Disponível em: $<$ http://g1.globo.com/rio-de-janeiro/noticia/2014/02/justica-declara-morte-presumida-deamarildo-desaparecido-desde-julho.html>. Acesso em: 10 jul 2015. 
JUSTINO, Guilherme. Zero Hora. Exposição traz nove corpos humanos a Porto Alegre. 2 de Julho de 2015. Disponível em: <http://zh.clicrbs.com.br/rs/noticias/planetaciencia/noticia/2015/07/exposicao-traz-nove-corpos-humanos-a-porto-alegre-4792959.html>. Acesso em 2 Jul. 2015.

LETA, Thamine. Jornal o Globo. Congelamento de corpo vira briga de família. 15 de Junho de 2012. Disponível em: <http://oglobo.globo.com/rio/congelamento-de-corpo-vira-briga-defamilia-5209334>. Acesso em: 3 Jul. 2015. A filha gasta $R \$ 27.000,00$ por mês para manter o corpo congelado.

R7. Funerária e hospital investigam vazamento de imagens do corpo de Cristiano Araújo. 25 de Junho de2015. Disponível em: <http://noticias.r7.com/cidades/funeraria-e-hospitalinvestigam-vazamento-de-imagens-do-corpo-de-cristiano-araujo-25062015>. Acesso em: 2 Jul. 2015.

(Artigo submetido em 13/07/2015 e aceito em 30/08/2015) 